\title{
Karman and Compassion: Animals in the Jain Universal History
}

\author{
EVA DE CLERCQ ${ }^{1}$ \\ Ghent University \\ Department of Indology \\ Blandijnberg 2-141 \\ 9000 Ghent \\ Belgium \\ Ev.DeClercq@UGent.be
}

\begin{abstract}
As a religious tradition which largely defines itself by its propagation of non-violence (ahimsāa) and respect for all living beings, Jainism gives particular attention to the wellbeing of animals, for example, in the prescription of a strict (lacto-)vegetarian diet, in advocating animal rights and the sponsorship of animal shelters. Against this background, this article examines the presence of animals and other non-human beings in Jaina mythology, more precisely the so-called Jaina Universal History. This Universal History in practice consists of the biographies (caritra or purāna) of 63 heroes (śalākā- or mahā-purusas), many of whom have parallels in broader South Asian epic, purānic or narrative traditions. This article introduces the various ways animals are dealt with in these Jaina purānic narratives, and will focus in particular on their symbolic value as representatives of human heroes.
\end{abstract}

KEYWORDS: animals; devotion; dharma; Jain Universal History; Jainism; karma; myth; non-violence (ahimsā); religion and nature.

A key outward characteristic of the Jain ideology is its efforts to ensure the welfare of animals. This is one of the first features which European colonizers described when they came into contact with the Jains (Glasenapp 1999: 4; Bender 1976: 116). Accounts of Jains entering the political arena to advocate animal protection are plenty. The most notable was the Śvetāmbara monk Hīravijaya who convinced the Mughal emperor Akbar to order a prohibition on the killing of animals around the sacred places and on festive days of the

1. Eva De Clercq completed her doctorate at Ghent University in Oriental Languages and Cultures (2003) with a critical study of Svayambhūdeva's Paumacariu, a Jain version in Apabhramiśa of the Rāmāyana, part of which is published as The Apabhramśa of Svayambhüdeva's Paumacariu (2009, Mumbai: Hindi Granth Karyalay). Since then, she has worked as a postdoctoral fellow on the Jain versions of the Sanskrit epics and Apabhramśa language and literature, and spent some years as a research fellow at the University of Würzburg. In 2010 she became Assistant Professor at Ghent University at the Department of Languages and Cultures of South and East Asia, where she teaches Sanskrit and Indian Literature. 
Jains (Dundas 2002: 145-47; Jaini 1998: 283-84; Glasenapp 1999: 74-77). World renowned are the numerous charitable animal hospitals (pāñjarāpol) run by Jains in accordance with Jain ideology (Lodrick 1981). Since 1990, individuals and organizations representing Jain communities in India and in the diaspora are striving to bring the Jain philosophy to the forefront of the global environmentalist movement, as a supreme ecology and defence of animal life, which has existed in India for over two millennia. ${ }^{2}$

This preoccupation with animal welfare is a practical manifestation of the vow of ahimsā, 'non-injury', central to Jain ethics and ideology. The importance of the ahimsa a principle is related to the belief, which Jains share with other Indic traditions, that a soul migrates between subsequent bodies, either human, animal, plant, infernal or divine, through the workings of karman. Causing injury, in the broadest sense, to a being results in the accumulation of demerit (pāpa) and a subsequent birth in a less favourable existence. Thus, according to this belief system, we may ourselves be reborn as an animal in a future life, or we may have been an animal in a previous life. The grey dove on our windowsill or our pet dog may be the incarnation of the soul of a loved one who has passed away. The essence of any creature, its soul, is not valued less than that of a human. It is only because of its specific collected karmic baggage at the time of its last death, that this soul has been reborn in an animal existence. Nevertheless, a life as an animal, a tiryañc (literally 'going horizontally', and referring to animals and plants), is considered the lowest form of existence. The tiryañc category of beings is divided into widely varying subgroups, depending on the number of sense faculties and on whether or not they have the capacity to reason, ranging from the nigoda, one-sensed, submicroscopic organisms at the bottom end, to five-sensed animals such as fish, birds, reptiles, amphibians and mammals at the top end (Jaini 1998: 108-11).

Like the famous Buddhist jātaka tales, Jain stories of transmigrating souls in animal existences are popular didactic tools for bringing across the theory of karm, and abound in Jain narrative literature, including the so-called 'universal history' of the Jains, a corpus of texts which narrate the traditional history of all creatures, naturally emphasizing humankind. Their focus is the biographies of a specific number, mostly 63, of heroes, the śalākāpurușas or mahāpurusas, 'great men' who are believed to have lived in the current era. These texts, which are called purānas or caritas, are considered a countertradition for the rise of Purānic Hinduism and as such include Jain variants of popular Hindu gods, protagonists and stories, such as Rāma and Krș̣na (Jaini 2000: 375-428; Cort 1993). The 63 śalākāpurușas comprise 24 tìrthaṃkaras, 'ford makers' or jinas, 'conquerors', prophet-like persons, born after long intervals in time, who realize omniscience (kevala) and subsequently spread the Jain faith in the world, 12 cakravartins, 'universal emperors' who each bring

2. An overview of international activities of such organizations is provided in Caillat (2009: 123-28). For discussions on Jainism and modern global environmentalism, see the papers in Chapple (2002).

(c) Equinox Publishing Ltd 2013.

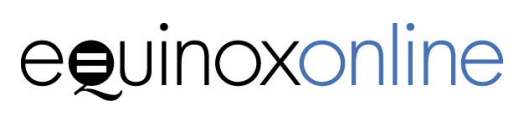


the six parts of Bhārata under a single dominion, and nine triads of baladevas, vāsudevas and prativāsudevas, who live simultaneously. The baladeva is the half-brother of the vāsudeva, who is destined to kill their common enemy, the prativāsudeva. Rāma and Krșna belong to these triads as respectively the eighth baladeva and ninth vāsudeva. A full list of the 63 śalākāpurușas is provided in Table $1 .^{3}$ Longer lists include additional categories, such as the mothers and fathers of the tìrthamkaras, 24 kämadevas, 11 rudras, 9 nāradas and 14 kulakaras under the śaläkāpurușas. ${ }^{4}$

Table 1. The 63 śalākāpurușas

\begin{tabular}{|c|c|c|c|c|}
\hline Tirthaṃkara & Cakravartin & Baladeva & Vāsudeva & Prativāsudeva \\
\hline Roșabha & Bharata & & & \\
\hline Ajita & Sagara & & & \\
\hline \multicolumn{5}{|l|}{ Sambhava } \\
\hline \multicolumn{5}{|l|}{ Abhinandana } \\
\hline \multicolumn{5}{|l|}{ Sumati } \\
\hline \multicolumn{5}{|l|}{ Padmaprabha } \\
\hline \multicolumn{5}{|l|}{ Supārśva } \\
\hline \multicolumn{5}{|l|}{ Candraprabha } \\
\hline \multicolumn{5}{|l|}{$\begin{array}{l}\text { Suvidhi } \\
\text { (Pușpadanta) }\end{array}$} \\
\hline Śreyāṃsa & & + Acala $/{ }^{*}$ Vijaya & Triprșțha & Aśvagrīva \\
\hline Vāsupūjya & & +Vijaya/*Acala & Dviprșțha & Tāraka \\
\hline Vimala & & +Bhadra/*Dharma & Svayambhū & $\begin{array}{l}\text { +Meraka/ } \\
\text { *Madhu }\end{array}$ \\
\hline Ananta & & Suprabha & Puruṣottama & $\begin{array}{l}\text { +Madhu/ } \\
\text { *Madhusūdana }\end{array}$ \\
\hline \multirow[t]{2}{*}{ Dharma } & Maghavan & Sudarśana & Purușasiṃha & $\begin{array}{l}\text { +Niśumbha/ } \\
\text { *Madhukrīḍa }\end{array}$ \\
\hline & Sanatkumāra & & & \\
\hline Śānti & (Śānti) & & & \\
\hline Kunthu & (Kunthu) & & & \\
\hline \multirow[t]{2}{*}{ Ara } & (Ara) & $\begin{array}{l}\text { +Ānanda/ } \\
\text { *Nandișeṇa }\end{array}$ & $\begin{array}{l}\text { +Purușapunḍarīka/ } \\
\text { *Punḍarīka }\end{array}$ & $\begin{array}{l}\text { +Bali/ } \\
\text { *Niśumbha }\end{array}$ \\
\hline & $\begin{array}{l}\text { +Subhūma/ } \\
\text { *Subhauma }\end{array}$ & +Nandana & + Datta & +Prahlāda \\
\hline Malli & *Padma & *Nandimitra & *Datta & *Balīndra \\
\hline
\end{tabular}

3. When different, the Śvetāmbara accounts, based on Hemacandra's Trișaștiśalākāpurușacarita are marked with an asterisk $(*)$, the Digambara accounts, based on Jinasena's and Gunabhadra's Mahāpurāna, are marked with a plus sign (+).

4. As in the Digambara treatise on cosmology Tiloyapannatti 4.1473. 


$\begin{array}{lllll}\text { Munisuvrata } & \text { +Mahāpadma } & \text { Padma (Rāma) } & \text { Lakṣmaṇa } & \text { Rāvaṇa } \\ & \text { *Harișeṇa } & & \\ \text { Nami } & \text { +Hariṣeṇa } & & & \\ & \text { Jayasena } & & & \\ \text { Nemi } & \text { Brahmadatta } & \text { Balarāma } & \text { Krṣ̣na } & \text { Jarāsandha } \\ \text { Pārśva } & & & & \\ \text { Mahāvīra } & & & & \end{array}$

Literary compositions on the Jain universal history contain different definitions of what a Jain purāna should entail (De Clercq 2005). Some authors explicitly mention that it should treat the gatis, the four modes of existence: (1) human, (2) hell being, (3) divine being or (4) tiryañc. This article will present an overview of the various kinds of animal presences in these Jain universal histories, literally, in the encounters between śalākāpurușas and animals, and figuratively, in the symbolic value of certain animal occurrences, and will conclude with an excursus on animal sacrifice. ${ }^{5}$

\section{ANIMALS AS SYMBOLS}

In the biographies of its heroes, particularly in the stories of the most revered tìrthamkaras, Jain authors make ample use of pan-Indian animal symbolism. They hereby deliver implicit additional emphasis on certain aspects of tirthamkara identity, and position the Jain heroes, and ultimately the entire Jain doctrine, in wider South Asian society and culture.

\section{DREAMS OF THE MOTHERS}

A typically Jain feature regarding the biographies of the śalākāpurusas is that, when their soul descends into the womb of their mother, the mother has a number of dreams, or rather a succession of images which appear to her in a dream. These images seem to relate to the place in the hierarchy held by the salākāpurusa category, though there is no complete consensus among authors from the different branches of Jainism. Śvetāmbaras list the number of images of the mother of a tirthamkara and a cakravartin as 14, of the mother of a vāsudeva as seven, and of a baladeva's mother as four. ${ }^{6}$ According to Digambara authors,

5. We leave out the abundant poetic metaphors and similes in the compositions under scrutiny. Compositions, narrating (part of) the Jain universal history, included in this study are the Mahāpurāna of Jinasena and Guṇabhadra, the Harivamiśapurāna of Jinasena Punnāța, the Paumacariyam of Vimalasūri and the Trișaștiśaläkāpurusacarita of Hemacandra.

6. This is the case in the best known and authoritative Śvetāmbara purāna: the Trișaștiśalākāpurușacarita by Hemacandra. 
the mother of a tirthamkara sees 16 images in a dream, but there is disagreement with regard to the other śalākappurusas. ${ }^{7}$ All authors however agree that the first three images seen by the mother of a tirthamkara are always of an elephant, a bull and a lion. Some authors explicit that these animals are white, and sometimes the elephant is described as having four tusks, resembling Indra's divine mount Airāvata. The significance of this dream motif is evident from the fact that it recurs in an important temple ritual, in which the pañca-kalyānakas, five auspicious events in the life of a tirthamkara, are re-enacted and celebrated. One of these auspicious events is the dream experienced by the mother (Jaini 1998: 196-99). It is also a favourite subject in Jain pictorial and sculptural art. The elephant, bull and lion as the first elements perceived by the mother are very telling for how the Jains view and honour their spiritual leaders. All three are wellknown as symbols of kingship and empire, at least since the time of the Aśokan pillars, where these three were favoured as capitals (Geer 2008: 26). Even though the vast majority of Jains since centuries have belonged to merchant classes, all the tìrthaṃkaras were born in royal families. According to Śvetāmbara accounts, Mahāvīra's soul first descended into the womb of a Brahmin woman, only to be later transposed by divine intervention into the womb of a kșatriya lady, underlining the importance of the kșatriya identity of tìrthamkaras. ${ }^{8}$ Every tìrthamkara is by birth destined for a political career, but instead chooses to renounce earthly kingship to become a spiritual leader. The symbolism of the elephant, bull and lion seen by the mother in a dream can be seen as reflections of the royal affiliations of the tìrthamkaras. ${ }^{9}$

\section{MARKS OF THE TĪRTHAMKARAS}

Aside from the animals in the dream of the mothers, there is another way in which animals occur as symbols in some biographies of the tirthamkaras. Hemacandra describes how every tìrthamkara is born with a particular lāñchana, 'mark', a list of which is provided in Table $2 .^{10}$

7. Gunabhadra's Mahāpurāna (14.123-29) mentions six dreams for the mother of a cakravartin. The Harivamśa Purāna of Jinasena Punnāṭa (34.13-15) describes seven dreams of the mother of the vāsudeva Krș̣na. For an overview of different accounts, see Chandra (1970: 384-87).

8. Note that this episode is absent in the Digambara biographies of Mahāvīra. There he directly descends into the womb of the kșatriya woman Triśalā.

9. In Śvetāmbara accounts, the dreams of the mother of a tīrthamkara and of a cakravartin are identical. Three tìrthamkaras of the present era experienced a fruitful career as a full cakravartin before renouncing the world and becoming a tirthamkara. The Digambara accounts, which only list six dreams announcing the birth of a cakravartin, do not refer to any of these three animals, instead mentioning other generally considered auspicious symbols. With regard to the tìrthamkaras Sānti, Kunthu and Ara, who were cakravartins prior to becoming tïrtham karas, Guṇabhadra's Uttarapurāna lists the 16 dreams for a tïrthaṃkara. For more on the notions of kingship in Jainism, see Babb (1993, 1994 and 1996).

10. Tiloyapaṇnatti 4.604-605 uses the term cihna, 'mark' instead of lāñchana. Shah (1987: 83) translates the term as 'cognizance'. When accounts differ, Śvetāmbara variants based on 
Table 2. Tïrthamkaras and their marks

\begin{tabular}{|c|c|}
\hline Tīrthaṃkara & Mark \\
\hline Rș̣abha & bull \\
\hline Ajita & elephant \\
\hline Sambhava & horse \\
\hline Abhinandana & monkey \\
\hline Sumati & *curlew (krauñca)/+cuckoo (koka) \\
\hline Padmaprabha & red lotus (padma) \\
\hline Supārśva & *svastika/+nandyāvarta \\
\hline Candraprabha & (half) moon \\
\hline Suvidhi/Puṣpadanta & makara (crocodile) ${ }^{11}$ \\
\hline Śītala & *śrīvatsa / +svastika \\
\hline Śreyāṃsa & rhinoceros \\
\hline Vāsupūjya & buffalo \\
\hline Vimala & boar \\
\hline Ananta & *hawk/+porcupine ${ }^{12}$ \\
\hline Dharma & thunderbolt \\
\hline Śānti & deer \\
\hline Kunthu & (he-)goat \\
\hline Ara & ${ }^{*}$ nandyāvarta/+fish ${ }^{13}$ \\
\hline Malli & jar (kalaśa) \\
\hline Munisuvrata & tortoise \\
\hline Nami & blue lotus \\
\hline Nemi & conch \\
\hline Pārśva & serpent \\
\hline Mahāvīra & lion \\
\hline
\end{tabular}

Hemacandra's Trișaștiśalākāpuruṣacarita are marked with an asterisk (*), Digambara accounts based on the Tiloyapannatti are marked with a plus sign (+).

11. According to Shah (1987: 84), the Pratișthāsāroddhāra (1228), a Digambara manual by Āśādhāra on the installation of tīrthamkara images has a crab as the emblem of Puspadanta.

12. Tiloyapannatti 4.605 reads sāhī, interpreted by the Hindi commentator as 'porcupine' (see also Turner 1966-1985: §12766 śvāvidh-). Hemacandra's text is quite clear (śyena, in Trișașțiśalākāpuruṣacarita 4.4.29). According to Shah (1987: 84), Pratișțhāsāroddhāra mentions a bear as the emblem of Ananta.

13. Tiloyapannatti 4.605 reads taragakusumā, 'floating flower'. The Hindi commentator interprets this as fish. 
In 16 out of 24 cases, these marks are animals. The origin and meaning of this motif remains vague, though they appear to be a later phenomenon, since such marks are not mentioned as regular attributes of tirthamkaras in the earlier biographies predating Hemacandra, except the Āvaśyakaniryukti (early sixth century), which states that Rșabha was born with the mark of a bull on his thigh. ${ }^{14}$ The addition of this motif in the tirthamkara biographies appears to stem from the prominence of these lāñchanas in iconographic representations of the tirthamkaras, where they are engraved on the pedestal of the icon and are generally the only identifier differentiating between the 24 tirthamkaras. ${ }^{15}$ According to Shah (1987: 85) they begin to occur regularly in artistic representations of the tirthamkaras from the fifth century onwards. Prior to that, from the second or first century BCE, a mark associated with a particular tïrthamkara seems to have been positioned on a pedestal or a pillar in front of a tìrthaṃkara shrine or image, as is evidenced from āyāgapațas from Kan̉kālī Ṭīlā dating from the first century CE (Shah 1987: 87; Quintanilla 2000: 86). In a subsequent phase, the mark was portrayed twice at the end of the pedestal flanking a dharmacakra, 'wheel of the faith', and only after that the emblem became central and the wheel was dropped. Cort (2010: 213-14) considers the fact that, excepting Pārśva, images of the different 24 tìrthamkaras would be unintelligible, were it not for the presence of the mark in the seat of the icon, as a deliberate strategy connected to the theological concept of the tirthamkara as a transcendent divinity, at the same time singular and plural. This idea is supported by the fact that the Śvetāmbara term lāñchana holds the connotation of 'stain, blemish', whereby the abstract transcendent divinity is somehow stained by the addition of the embodying marker. Striving towards coherence between the textual and iconographic representation of the tirthamkaras, Hemacandra seems to have been the first to include references to the different marks in his biographies. With regard to the choice of a specific mark for a specific tìrthaṃkara, Shah refers to a verse in Āsādhāra's Pratisțhāsāroddhāra, which says that the mark on a jina icon is that "which is recognized individually on account of [his] family, greatly honorable in the world'. ${ }^{16}$ Shah interprets this as denoting the charges of heraldry (dhvajas) which, according to him, every kșatriya family possessed. ${ }^{17}$ It thus seems that, with the gradual extension of the list of tirthamkaras to 24 and a growing need to differentiate among them in iconographic representation, the idea rose to

14. Note that Hemacandra also specifies that Rșabha was born with the mark of a bull on his thigh. For the other tirthamkaras he is not specific with regard to where or how this 'mark' should be visualized.

15. The exception is the image of Pārśva who is typically represented together with the serpent Dharanendra.

16. vaṃse jagatpūjyatame pratītam prthagvidham tīrthakrttām yad atra. Author's translation. tal lāñchanaṃ saṃvyavahārasiddhayai bimbe jinasyeha niveśayāmi (from Shah 1987: 108).

17. Warriors having individual emblems are described in Mahābhārata 4.50.4-22, 7.80.2-29, 6.17.18-39 and 6.45.7-33 (cf. Brockington 1998: 185).

(c) Equinox Publishing Ltd 2013.

\section{equinoxonline}


assign an insignia to each tīrthamkara. Not only did this pragmatically enable artists to embody the individual tirthamkara, but in so doing it again underscored the warrior descent and nature of the tirthamkara.

\section{ANIMAL ENCOUNTERS IN THE UNIVERSAL HISTORY}

\section{ANIMALS AS PREVIOUS EXISTENCES}

A significant part of the biographies of the great heroes in the Jain purānas concerns their previous existences. Accounts of previous births as animals are relatively rare among the śalākāpuruṣas. This seems to relate to the relatively low status of an animal existence, as opposed to the comparatively high spiritual maturity of most of these heroes. The last cakravartin Brahmadatta, for instance, long before his birth as a śalākāpuruṣa, experienced an existence as a deer, in which he was killed by a hunter, followed by a life as a swan, in which he died at the hands of a fisherman. ${ }^{18}$ Even though he reached a superior state of martial valour as a cakravartin, he was not very evolved spiritually, committing grave sins which lead to a rebirth in hell. ${ }^{19}$ A parallel situation occurs in the previous lives of the Rāmāyana characters. After an existence in which the souls of four protagonists Rāma, Lakṣmaṇa, Sītā and Rāvaṇa coexisted and interacted, and in which the enmity between the souls of Lakṣmaṇa and Rāvaṇa for the sake of Sītā is introduced, Rāma's soul goes through a number of existences as a human or in heaven, completely separated from the souls of Lakșmaṇa, Sītā and Rāvaṇa, who are reborn in subsequent animal existences in a forest, fighting each other incessantly: deer, boars, elephants, buffaloes, oxen, monkeys, and many unnamed others. ${ }^{20}$ In concordance with Brahmadatta's case, the baladeva Rāma attains omniscience and escapes samsāra, 'the cycle of transmigration', forever, whereas Lakșmaṇa and Rāvaṇa are born in hell, Sītā in heaven. Thus, there appears to be a tendency in the Jain purānas that animal existences in the not too distant past indicate a lower level of spiritual development. There are, however, important exceptions to this tendency in the accounts of tirthamkaras who were animals in a relatively recent previous life.

The narrations of the previous existences of the most popular of the tīrthaṃkaras, Mahāvīra, Pārśva, Nemi and Śānti, tend to be the most drawn out and complex. In a previous life, Mahāvīra was Triprșțha, the first vāsudeva of this era. It is predicted that the first prativāsudeva, Aśvagrīva, will be killed by whoever kills the lion living near his rice fields. Aśvagrīva asks Triprșțtha to

18. Trișaștiśalākāpurușacarita 9.1.16-20 (Johnson 1931-1962: vol. 5, 318).

19. Trișaștiśalākāpuruṣacarita 9.1.600 (Johnson 1931-1962: vol. 5, 355).

20. Vimalasūri's Paumacariyam 103.1-123. Note that Hemacandra 7.10.24 only mentions the existence as deer. This account is absent in Gunabhadra's Uttarapurāna. For variations in the different Jain Rāma stories, cf. Chandra (1970: 187-91). 
protect the rice fields from the lion. Triprst tha goes to the lion's cave and challenges the animal. The lion attacks and Triprst tha tears him into two pieces in a very heroic way and accompanied by auspicious occurrences, such as a rain of flowers, fragrant wind, and so on. ${ }^{21}$ When Triprsțtha has later fulfilled his destiny by killing the prativāsudeva Aśvagrīva, he dies and is reborn in one of the hells. After that, he is himself reborn as a lion on a mountain near the Ganga (Ganges river). Because of the sins committed as a predatory animal, the lion after death is born in hell, after which he is again reborn as a lion in the Himālaya. One day, as he is eating a deer which he had just caught, two munis (ascetic sages) pass by. They halt and instruct the lion about its previous existence as Triprstitha and his subsequent lives as a hell-being and as a lion near the Gangā. The lion remembers and begins to weep. After hearing the narration of his other previous existences, the lion bows to the munis, encircles them in reverence and takes up the vows of a layman. He commences a fast, dies and is reborn in heaven.$^{22}$ Later, he will be born as Mahāvīra, marked with a lion.

Another popular account of a tirthamkara as an animal in his previous existence is found in the biography of Mahāvīra's predecessor, the twentythird tìrthamkara Pārśva. After concluding a life as a pious man in 'painful meditation' (ārta-dhyāna), while being stoned to death by his own brother, the soul of Pārśva is born as an elephant in the forest. In this elephant existence, he is reminded of his previous life by a muni. The elephant accepts the layman's vows and is killed by a kukkuța serpent, who was his murderous brother from his previous life. He is subsequently born in heaven. ${ }^{23}$ This story demonstrates the frequently recurrent motif of ārta-dhyāna as leading to an animal existence. Jains classify meditation (dhyāna) into four types, two of which can occur spontaneously, but may be detrimental to one's spiritual advancement, and which are therefore to be avoided. The first of these two is ärta-dhyanna, the preoccupation with something unpleasant or painful, such as thinking of a lost thing or person, thinking of something disagreeable, physical or mental pain, or longing for unattainable objects (Jaini 1998: 252; Glasenapp 1999: 236-37). The motif of a person dying while performing ārta-dhyāna, and being reborn as an animal on account of it, is common in Jain narratives. ${ }^{24}$

21. Trișaștiśaläkāpurușacarita 4.1.394-406 (Johnson 1931-1962: vol. 3, 28-29); the account of Triprștha killing the lion is absent in the Uttarapurāna.

22. Mahāpurāṇa 74.120-219; Trișaștiśálākāpurușacarita 10.1.182 (Johnson 1931-1962: vol. 6, 14). Note that Hemacandra does not give a description of the life of Mahāvīra as a lion.

23. Trișaștiśáāakāpuruṣacarita 9.2.56-108 (Johnson 1931-1962: vol. 5, 359-63); Bloomfield (1985: 39); Mahāpurāna 73.12-24. The popular stories of Pārśva's previous existences are performed during the annual Pauș Daśmī festival. For a description, see Babb (1996: 26-32).

24. See, for instance, the story of Danḍaka in Trișaștiśálākāpurușacarita 1.1.435 (Johnson 19311962: vol. 1, 45). On ārta-dhyāna leading to a rebirth as a tiryañc, see Varni (1997-2000: vol. 1, 275). 
More importantly both stories of Pārśva's and Mahāvīra's previous existence as an animal exemplify that all five-sensed animals, possessed of a mind, are capable to advance on the path towards spiritual liberation. A being in heaven and in hell is never able to make spiritual progress, which is reserved exclusively to humans and the higher category tiryañc. After hearing a muni give instruction, or otherwise remembering its previous existence, an animal can take up a form of the layman's vows, such as fasting, refraining from injuring other beings, and so on. Its reward is a better existence in its next life, either as a human, so that it may continue its spiritual advancement, or as a being in one of the heavens. ${ }^{25}$

When comparing the animal existences of the two tirrthamkaras with those of the cakravartin Brahmadatta and the vāsudeva Lakșmaṇa and prativāsudeva Rāvaña, one can distinguish a hierarchy paralleling their positions as śalākāpuruṣas. It is probably no coincidence that Pārśva and Mahāvīra were an elephant and a lion, the most regal of the animals, in a former life, again underlining the royal aspect of the tirthamkara. The existences of the lower śalākāpurușas as deer, swans, and so on, appear, in comparison, much more trivial. Moreover, there seems to be a greater multiplicity and randomness of animal births among the lower śalākāpurusas, absent in that of the tīrthamkaras.

\section{EFFECT OF THE TİRTHAMKARAS ON ANIMALS}

There are many instances in the universal history of animals being in the presence of a tirthamkara and benefitting after hearing a sermon. Such accounts emphasize that Jainism is a universal ideology, the benefits of which can be experienced by all creatures.

This universality is evident from the samavasarana, the 'universal preaching hall' which is constructed by the gods every time a tirthamkara holds a sermon. When a tirthamkara has reached omniscience, the gods hurry to the place where he or she is located. They cleanse the surface of the earth, sprinkle it with fragrant water, cover the area with gold, gems and flowers, and build jewelled arches in the four directions. Then they construct an inner rampart of gems, a second rampart of gold and a third outer rampart of silver. In the middle of the samavasarana, a tree is placed over a jewelled platform with a throne for the tirthamkara to sit. Gods and humans take place in the enclosure closest to the jina, within the first rampart. Animals take place within the second rampart, and the space within the third rampart is reserved for the animal vehicles of the gods. ${ }^{26}$ Every creature becomes blissful listening

25. From Jaini's study (2000: 253-66) it appears that the concept of animals pursuing spiritual progress by taking over the behaviour of pious laymen was also common in Buddhism.

26. These vehicles are regarded as a low category of gods, the Abhiyogas. See Varni (1997-2000:

C Equinox Publishing Ltd 2013.

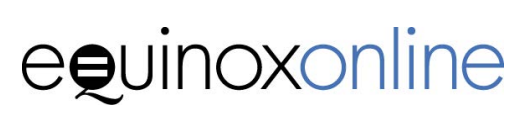


to the words of the jina, abandoning their instinctive enmities and fears, as described by Rșabha's son on the occasion of the first samavasarana:

This elephant has come to your assembly and, drawing with his trunk the lion's paw, frequently scratches his temple. Now the buffalo rubs the neighing horse with his tongue frequently from affection, as if he were another buffalo. The deer here, with pricked-up ears and his tail waving from pleasure, his face bent, smells the tiger's face with his nose. This young cat embraces the mouse running at his side, in front, and behind, as if it were his own offspring. This serpent, fearless, coiled in a circle, sits like a friend in the vicinity of a large ichneumon. O Lord, whatever creatures have been eternal enemies, they remain here free from hostility. For this is your unequaled power. ${ }^{27}$

A remarkable story of an animal receiving instruction takes place at the samavasarana of the twentieth Tirthamkara Munisuvrata in Bhrgukaccha, modern day Bharuch. The first disciple (ganadhara) of Munisuvrata asks who has adopted the Jain dharma at the samavasarana. Munisuvrata replies that no one has adopted it, except the high-bred horse of the king. The king requests to hear the story of the horse and Munisuvrata explains that in its previous life, the horse was a pious merchant who had a golden statue of a jina made. One day he went to a Śaiva temple where priests were moving jars of ghee, crushing the many ants that had clustered beneath the jars. When the merchant noticed this, he began gently to remove the ants with his garment out of compassion. Feeling insulted, one priest crushed the ants with his feet. The merchant nevertheless gave ear to the instruction of a Śaiva ācārya there, performed the Śaiva rites and was therefore reborn as a horse, nevertheless by nature possessing good character. Munisuvrata adds that he has come to that place to enlighten the horse. The king then sets the horse free and from then on, this place, Bhrgukaccha, is the sacred place Aśvāvabodha, a famous Śvetāmbara pilgrimage site. ${ }^{28}$ A rebirth as a high-bred horse is here considered to be among the best of animal births. The merchant is said to owe this to his liberality and the fact that he had installed a golden icon of the tirthamkara. His birth as the horse of a king enabled him to come into the presence of Munisuvrata and ultimately progress spiritually on the Jain path to salvation. ${ }^{29}$

Independent of a samavasarana is the following important encounter with an animal from Pārśva's biography. As a prince, before renouncing the world, Pārśva one day went to view the penances of an ascetic. He noticed a snake trapped in a piece of wood in a fire. He ordered the wood to be taken from the fire. The snake was already burnt and with compassion, Pārśva recited

vol. 1, 130). Some descriptions, such as that of Jinasena in his Ādipurāna (chapter 22 and 23) go into great detail on the construction of the samavasarana.

27. Trișaștiśáāakapurușacarita 1.3.543-49 (as translated by Johnson 1931-1962: vol. 1, 198-99).

28. Its story is narrated in the pilgrimage manual Vividhatīrthakalpa of Jinaprabhasūri (fourteenth century) as kalpa 10. Note that the Digambara texts are completely silent about this episode. The pilgrimage site Aśvāvabodha appears to be exclusively Śvetāmbara.

29. Trișaștiśalākāpurușacarita 6.7.198-220 (Johnson 1931-1962: vol. 4, 85-87). 
the namaskāra mantra to it. As a result of the auspiciousness from hearing the mantra, the snake died in meditation and was reborn as the Nāgakumāra god Dharaṇendra. Later he protected Pārśva when he was attacked by his transmigratory enemy, who created a storm to hinder his ascetic practice. This story is moreover behind the famous iconographic representation of Pārśva with Dharanendra. ${ }^{30}$

An account from Mahāvīra's biography illustrates his compassion for all living beings and the overall enlightening power of the presence of a tīrthamkara. While roaming, Mahāvīra one day passes a place where an angry serpent lived. People advise him not to go near the animal. Mahāvīra knew of the circumstances under which this soul had the misfortune of being born a serpent: he was an ascetic who one day kicked a frog and chose to ignore it. When his disciple remarked that he had 'forgotten' to confess his injury to the frog, the ascetic angrily rushed upon the boy with murder on his mind, but ran into a pillar and died. After an existence as a god, the soul of the ascetic was born as a man, the bad-tempered abbot of a group of ascetics. One day, while angrily trying to kill someone, he fell on his own axe, splitting his own head. He was then born as the angry serpent. Mahāvīra enters the wood inhabited by the snake to meditate. The snake attacks Mahāvīra again and again, but Mahāvīra remains unmoved. When Mahāvīra addresses him, he remembers his previous life, repents and starts to fast. Passers-by begin to honour the serpent, rubbing it with ghee. This attracts ants that come to eat away the ghee. After a fortnight of staying immovable, the serpent dies from being eaten by the ants and is reborn in one of the heavens. ${ }^{31}$

Some famous encounters with animals are found in the biography of the sixteenth jina Sānti, albeit in his previous existence as prince Megharatha. One day a cockfight is held. Two cocks fight for a very long time without one prevailing. On Megharatha's request, his austere father, the king, narrates the story of their previous births to explain their current condition. They once were two befriended merchants who deceived their customers. Because of their deceit, they died in ārta-dhyāna and were reborn as elephants. In a first elephant existence, they quarrelled, fought and died, to be reborn again as elephants in separate herds. When they one day saw each other, they rushed towards each other, battled and both died. They continued to fight in subsequent battles as buffaloes, rams and eventually cocks. The cocks renounce the world, fast and die, to be reborn as gods. Remembering their previous existence, they create an aerial car and invite Megharatha, whom they consider their benefactor in their life as cocks, for a journey around the world. This is an illustration of the benefits one may incur when taking care of animals..$^{32}$

30. Trișaștiśalākāpuruṣacarita 9.3.217-27 (Johnson 1931-1962: vol. 5, 392); Mahāpurāna 74.101-19 and 74.139-41. For studies of Pārśva's association with Dharaṇendra, see Dhaky (1997).

31. Trișaștiśalākāpurușacarita 10.3.225-80 (Johnson 1931-1962: vol. 6, 54-58).

32. Trișaștiśalākāpuruṣacarita 5.4.66-187 (Johnson 1931-1962: vol. 3, 279-86). A variant story can be found in Mahāpurāna 63.150-223.

(c) Equinox Publishing Ltd 2013.

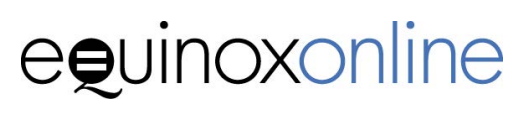


The most famous story of Megharatha's greatness is narrated later. One day a dove fell into his lap seeking refuge with him. The bird, in a human voice, asked to be rescued, and the king conceded. Thereupon a hawk approached, asking the king to turn the dove loose, because it was his food. The king refused because it is against the kșatriya code to deny refuge to a creature asking for help. He moreover rebuked the hawk for pursuing momentary satisfaction by eating meat, which inevitably results in a rebirth in hell. He suggested the hawk should find inanimate food. The hawk declined and then himself formally asked refuge with the king, who was now obliged to care for him. The bird reiterated his request for meat. Megharatha offered his own flesh to the hawk, to the same amount as the weight of the dove. The dove prospered and became heavier, so every time Megharatha had to offer more of his own flesh to the hawk, until he ultimately presented his entire body for food. When his retinue observed this, they protested that they also needed his protection, for which he had to keep his body in good condition. Thereupon a god appeared who explained that the whole ordeal was arranged by him, as he wanted to test Megharatha's famous compassion. The dove and the hawk fought each other because of an enmity from a former life. Remembering their previous life and instructed by Megharatha, they took to fasting and when they died, they were reborn as gods. ${ }^{33}$

In both cases the animals are freed from an apparent vicious cycle of confrontation by Megharatha's intervention. The second story is an adaptation of the famous story of king Sibi found in the Mahābhärata and the Buddhist Jātakas. ${ }^{34}$

\section{EFFECT OF ANIMALS ON THE TĪRTHAMKARAS}

Aside from spiritual progress made by animals from encountering a tìrthamkara, sometimes a tìrthamkara himself benefits from meeting an animal. The twentieth tìrthamkara Munisuvrata, for instance, was impelled to renounce the world upon seeing an elephant in the forest abstaining from food. The elephant had remembered its previous existence in which he was a man who had chosen the wrong faith and was therefore reborn as an animal. Disgusted with transmigration, the elephant began to fast to achieve spiritual advancement. ${ }^{35}$

The most famous and dramatic encounter with animals leading to a tìrthamkara's renunciation is that of the twenty-second tìrthamkara Nemi. In due course a marriage was arranged between handsome young prince Nemi and princess Rājīmatī. While Nemi was in his chariot, on the way to his bride

33. Trișaștiśalākāpuruṣacarita 5.4.253-313 (Johnson 1931-1962: vol. 3, 291-95); For Guṇabhadra's variant account: Mahāpurāna 63.253-79.

34. For a comparison of different versions of this story, see Meisig (1995).

35. Mahāpurāna 67.31-37. This motif is absent in Hemacandra's biography of Munisuvrata.

(c) Equinox Publishing Ltd 2013.

\section{e evinoxonline}


to be married, he was distracted by the sound of the animals waiting to be slaughtered for the wedding banquet:

As Nemi went along, he heard the pitiful cries of animals and asked his charioteer: 'What is this?' though he knew well. The charioteer replied: 'Lord, do you not know? These various animals have been brought here to provide food for your marriage. Earth-dwellers, goats, et cetera and sky-dwellers, partridges, et cetera, belonging to village and forest, these will die, master. These are being watched by guards inside enclosures, crying out. For fear of life is a great fear of all.'

Then Nemi, a hero of compassion, said to his charioteer, 'Drive my chariot to the place where these animals are.' The charioteer did so; and the Blessed One saw many animals, their hearts terrified at losing their lives. Some were fastened by ropes on the neck, some on the feet, some had been thrown into cages and some had fallen into snares. Their faces upturned, their eyes pitiful, their bodies trembling, they looked at Nemi friendly from (his) appearance. 'Protect! Protect!' they said to Nemi, each in his own language. Neminātha, giving orders to the charioteer, had them released. When the animals had gone to their respective places, the Lord had the chariot turned back towards his own house. Śivā, Samudravijaya, Krșna, Rāma, and others left their own conveyances and were in front of Nemi. Śivā and Samudravijaya, their eyes filled with tears, said: 'Why have you suddenly turned away from this festival?' Nemi said: 'Just as these animals were bound by bonds, so we are bound by bonds of karma. Just as there was release from bondage for them, so I shall take initiation to make my own release from the bondage of karma-the sole source of happiness. ${ }^{36}$

After these words, young Nemi abandoned his marriage plans and immediately renounced the world, to the dismay of his relatives and his waiting bride Rajīimatī. The sheer contrast between the splendour and cheerfulness of the royal wedding organization, on one hand, and the anguish of the innocent animals waiting to be slaughtered, on the other, is what makes this episode so striking and Nemi's decision so touching. Its popularity is evident from the literary adaptations and the ample illustrations found in manuscripts narrating this story. ${ }^{37}$

\section{EXCURSUS: THE ORIGIN OF ANIMAL SACRIFICE ACCORDING TO THE JAINS}

In this article we discussed how Jain authors used standard South Asian animal symbolism to underscore the kșatriya identity of the tirthamkara and how factual animal presences in the lives of the śalākāpurușas, particularly of

36. Trișaștiśalākāpurușacarita 8.9.171-84 (as translated by Johnson 1931-1962: vol. 5, 25859). Colette Caillat (2009: 143) provides the translation of the parallel passage in the Uttarādhyāyanasūtra. See also Harivamiśa Purāṇa 55.85-100 and Mahāpurāṇa 71.158-68. Note that according to Gunabhadra this was prearranged deliberately by Kṛṇa to kindle Nemi's longing for renunciation.

37. For instance, the messenger poem Nemicarita by Vikrama (fourteenth century). See Jaini (2000: 372). 
the tirthamkaras, emphasize the universality of the Jain doctrine, as effective for all living beings trapped in samsāra through the workings of karman, and appeal for awareness and compassion for souls stuck in lowly tiryañc existences. Though ahimsā and a general benevolence towards animals are common to most South Asian religions, the Jains stress its importance to an extreme.

One tenet, in which Jainism views itself as very distinct from Brahmanical ideology, is its rejection of animal sacrifice. The story behind the origin of animal sacrifice is told in the Jain universal history by Nārada to the eighth prativāsudeva Rāvana. ${ }^{38}$ In his youth Nārada once took instruction with a teacher, together with two other pupils. One day two ascetics prophesied that only one of the teacher's pupils would go to heaven, the other two would go to hell. To test his pupils, the teacher gave each a cock made of dough and ordered them to kill it where nobody could see. Nārada's fellow students went and secretly destroyed the dough cocks. Nārada went away with his dough cock and reflected, ultimately deciding that he could not destroy it, securing his place in heaven. Of the three pupils, one became a king, the other, who was the son of the teacher, became a teacher himself, expert in the Vedas. Their old teacher became a Jain mendicant. Years later, Nārada returned and overheard his fellow student, the son of his teacher, explain that according to the Rgveda, sacrifice must be made with an aja, meaning a goat. Nārada interrupts that he is making a mistake and that aja signifies three year-old rice, which is called thus, because it no longer reproduces $(a-j a)$. They argue and make a wager that whoever is wrong, must have his tongue cut out. They decide to leave it to the third pupil, who was by now king. Secretly, the wife of the old teacher, mother of the Veda expert, goes to the king to request his favour. The king concedes, and she asks him to answer the question regarding the meaning of aja in sacrifice wrongly. Reluctantly, the king yields and, out of loyalty to his teacher, testifies that aja means goat. From then on, Brahmins have been sacrificing goats, countless innocent animals have been pointlessly put to death and countless ignorant sacrificers have collected inauspicious karman, because of a lie to protect the tongue and the honour of a mistaken Veda teacher. This story exemplifies how Jains view themselves as advocates of animals in a world where, as they see it, many do not view animals as equal to other beings.

\section{REFERENCES}

Babb, L. A. 1993. 'Monks and Miracles: Religious Symbols and Images of Origin among Osval Jains.' Journal of Asian Studies 52(1): 3-21. http://dx.doi.org/10.2307/2059142

- 1994. 'The Great Choice: Worldly Values in a Jain Ritual Culture.' History of Religion 34(1): 15-38. http://dx.doi.org/10.1086/463380

- 1996. Absent Lord: Ascetics and Kings in a Jain Ritual Culture. Berkeley: University of California Press.

38. Trișașțiśalākāpurușacarita 7.2.363-502 (Johnson 1931-1962: vol. 4, 141-51); Paumacariyam chapter 11 .

(C) Equinox Publishing Ltd 2013.

\section{eevinoxonline}


Bender, E. 1976. 'An Early Nineteenth Century Study of the Jains.' Journal of the American Oriental Society 96(1): 114-16. http://dx.doi.org/10.2307/599898

Bloomfield, M. 1985. The Life and Stories of the Jaina Savior Pārçvanātha. Delhi: Gian Publishing House.

Brockington, J. 1998. The Sanskrit Epics (Handbuch der Orientalistik, Indien-12). Leiden: E. J. Brill.

Caillat, C. 2009. 'Les jaina et le règne animal.' In N. Balbir and G. Pinault (eds), Penser, dire et représenter l'animal dans le monde indien: 123-55. Paris: Librairie Honoré Champion.

Chandra, K. R. 1970. A Critical Study of Paumacariyam. Muzaffarpur: Research Institute of Prakrit, Jainology and Ahimsa Vaishali.

Chapple, C. K. (ed.). 2002. Jainism and Ecology: Nonviolence in the Web of Life. Cambridge: Harvard Divinity School.

Cort, J. 1993. 'An Overview of the Jaina Purāṇas.' In W. Doniger (ed.), Purāna Perennis: Reciprocity and Transformation in Hindu and Jaina Texts: 185-206. New York: State University of New York Press.

- 2010. Framing the Jina. Narratives of Icons and Idols in Jain History. Oxford: Oxford University Press.

De Clercq, E. 2005. 'The Jain Rāmāyaṇa-Purāṇa: Paumacariyam - Padmacarita - Paumacariu.' In P. Koskikallio (ed.), Epics, Khilas and Purānas: Continuation and Ruptures (DICSEP III): 597-608. Zagreb: Croatian Academy of Science.

Dhaky, M. A. 1997. Arhat Pārśva and the Dharanendra Nexus (B. L. Series No. 11). Delhi: Bhogilal Leherchand Institute of Indology.

Dundas, P. 2002. The Jains. Reprint 1992. London: Routledge.

Geer, A. van der. 2008. Animals in Stone. Indian Mammals Sculpted through Time. Leiden: E.J. Brill. http://dx.doi.org/10.1163/ej.9789004168190.i-462

Glasenapp, H. von. 1999. Jainism-an Indian Religion of Salvation: An English Translation of Der Jainismus-eine Indische Erlösunsreligion by Shridhar B. Shrotri. Delhi: Motilal Banarsidass.

Jacobi, H., and M. S. Punyavijayaji (eds). 1962-1968. Ācārya Vimalasūri's Paumacariyam with Hindi translation (2 vols.) (Prakrit Text Society Series Nos. 6 and 12). Varanasi and Ahmedabad: Prakrit Text Society.

Jain, P. (ed.). 1954. Mahāpurāna (Vol. II): Uttar Purāna of Acārya Gunbhadra-with Hindi translation (Jñānapītha Mūrtidevi Jaina Granthamālā-Sanskrita Grantha No. 14). Kāshī: Bhāratīya Jñānapitha.

- (ed.). 1963-1965. Ādipurāṇa of Āchārya Jinasena (2 vols.) (Jñānapītha Mūrtidevī Jaina Granthamālā Sanskrit Granth Nos. 8-9). Kāshī: Bhāratīya Jñānapītha.

- (ed.). 1978. Harivamiśa Purāna of Jinasena (Jñānapiṭha Mūrtidevī Jaina Granthamālā Sanskrit Grantha Nos. 27). New Delhi: Bharatiya Jnanpith.

Jaini, P. S. 1998. The Jaina Path of Purification. Reprint 1979. Delhi: Motilal Banarsidass.

Jaini, P. S. (ed.). 2000. Collected Papers on Jaina Studies. Delhi: Motilal Banarsidass.

Johnson, H. (trans.). 1931-1962. Trișaștiśáāāāpurușacaritra (6 vols.) (Gaekwad's Oriental Series, Nos. LI, LXXVII, CVIII, CXXV, CXXXIX \& CXL). Baroda: Oriental Institute.

Lodrick, D. O. 1981. Sacred Cows, Sacred Places. Origins and Survivals of Animal Homes in India. Berkeley: University of California Press.

Meisig, M. 1995. König Śibi und die Taube. Wandlung und Wanderung eines Erzählstoffes von Indien nach China. Wiesbaden: Harrassowitz Verlag.

Quintanilla, S. R. 2000. 'Āyāgapațas: Characteristics, Symbolism, and Chronology.' Artibus Asiae 60(1): 79-137. http://dx.doi.org/10.2307/3249941

Shah, U. P. 1987. Jaina-Rūpa-Mandana-Volume I. New Delhi: Abhinav Publications.

Śrīcaraṇavijayajī Mahārāj, Śrīpunyavijayajī Mahārāj, Śrīramaṇakavivijayajī Gaṇī and Vijaya śīlacandrasūri (eds). 1990-2006. Trișaștiśalākāpurușacaritamahākāvyam (4 vols.). Ahamadābād: Kalikālasarvajña Śrīhemacandrācārya Navama Janmaśatābdī Smṛti Śikṣaṇ Saṃskāranidhi.

Sukthankar, V. S. (ed.). 1933-1966. The Mahābhārata (19 vols.). Poona: Bhandarkar Oriental Institute.

Turner, R. L. 1966-1985. A Comparative Dictionary of the Indo-Aryan Languages (4 vols.). London: Oxford University Press.

\section{eevinoxonline}


Upadhye, A. N., and H. Jain (eds). 1951-1956. Jadivasaha's Tiloya-Pannatti (2 vols.) (Jivaraja Jain Granthamala No. 1). Sholapur: Jaina Samskriti Samraksaka Samgha.

Varni, J. 1997-2000. Jainendra Siddhānta Kośa (5 vols.) (Moortidevī Jain Granthamālā: Sanskrit Grantha Nos. 38, 40, 42, 44 and 48). Reprint 1921-1983. New Delhi: Bharatiya Jnanpith.

Vijaya, Jina (ed.). 1934. Vividha Tïrtha Kalpa of Jinaprabha sūri (Singhi Jaina Series No. 10). Śāntiniketan: Sañcālaka, Singhī Jaina Granthamālā.

(c) Equinox Publishing Ltd 2013.

\section{eevinoxonline}

